\title{
Religion and Covid-19 in the Era of Post-Truth: The Case of Indonesia
}

\author{
ASFA WIDIYANT0 ${ }^{1}$
}

\begin{abstract}
Coronavirus disease (Covid-19) has become global pandemic, which affects all countries in the world including Indonesia. The mitigation of covid-19 pandemic in Indonesia cannot neglect the role of religion, since religion constitutes the main identity of most people. Hence, religion becomes value reference and 'system of knowing', including in addressing the covid-19 pandemic. By employing comparative and content analysis, it is hoped that this paper will constitute a significant contribution in unravelling the complex role of religion in dealing with covid-19 pandemic, most particularly in the context of post-truth. There are three concerns of this paper. First, it examines the challenges of religious conservatism towards covid-19 mitigation among Indonesian Muslims, most particularly in the context of post-truth which in some ways intensifies the emergence of conservativism in the public space. Second, it explores the possibility of 'new spirituality' which is pertinent for the mitigation of Covid-19. Third, it explores the contribution of Indonesian Muslim knowledge culture to the fight against covid-19.
\end{abstract}

Keywords: Covid-19, Indonesian Islam, knowledge culture, new spirituality, posttruth

Coronavirus disease (Covid-19) swayed all countries in the world, including such a superpower country as the United States. In this vein, Covid-19 pandemic constitutes a test for a nation in terms of political, food, economic and health security. An established country is ideally able to sustain these four domains of security. In practice, not all these four domains can be equally safeguarded. Under these conditions, the government normally give more priorities to health and food security. If these two domains can be saved, politics will become stable because people's trust in the government is maintained. Some countries prioritised health security over economic security due to the consideration that human life is more valuable than economic growth. The leaders of these countries argue that people who died could not be brought to life, but the economic sluggishness could be revived by hard work and political will.

In fighting covid-19, a nation is in needs of strong social capital. One of the important social capitals is community's compliance with health protocols. In democratic countries, this obedience cannot be imposed from the top with a repressive approach and super-heavy sanctions. Even though rules and law enforcement have to exist, it is not the only way that the government may use to make people obedient. Compliance which is based on personal awareness or religious values can be an alternative to develop social capital in mitigating of covid-19 pandemic.

In responding to Covid-19 pandemic, some people are more attentive to religious authorities rather than state authorities. Regulations from state authorities will only be acknowledged by some people if they have been translated or mediated by religious authorities. Legal opinions (fatwa) issued by the Council of Indonesian Muslim Scholars (MUI), the

\footnotetext{
${ }^{1}$ Asfa Widiyanto, Ph.D., Professor of Islamic Thought at the State Institute for Islamic Studies (IAIN) Salatiga, Pulutan, Sidorejo, 50716 SALATIGA, Jawa Tengah, Indonesia, email: widiyanto_asfa@daadalumni.de.
} 
Muhammadiyah and the Nahdatul Ulama, in some ways, serve as 'translations' and 'appropriations' of government regulations. In this regard, Abdurrahman Wahid's standpoint that Muslim scholar (kyai) represents a social broker is worth remarking. Muslim scholar, in this case, can be expanded into Islamic civil society organisations.

It is of interest to investigate further the mitigation of Covid-19 in Indonesia due to the fact that religion plays a significant role in Indonesian public sphere. The combat against covid19 in the country is accordingly unconceivable without taking an appropriate attention to religion, most specifically Islam as the religion of the majority. The post-truth era which accentuates belief and personal inclination in addressing information and truth, makes the role of religion in the context of the covid-19 pandemic more complex. This research focuses on the experiences of Indonesian Muslims in dealing with Covid-19, most specifically from March to June 2020.

\section{Covid-19 and Digital Literacy: The Challenges of Post-Truth}

In authoritarian countries, media are under the control of the government, so they lack the flexibility in presenting information about covid-19 that ostensibly could threaten the authority of the government. Democratic countries have advantages in terms of media freedom, since press freedom is one of the pillars of democracy. The media plays an important role in providing information about the development of the covid-19, while at the same time controlling government policies.

Covid-19 has a different context from its predecessors, SARS and MERS viruses. Covid-19 spreads in the digital age, where information comes not only from the mainstream media but also on social media. Social media, most specifically in democratic countries, present alternative information pertaining to Covid-19, which are in some ways distinct to the mainstream media. In terms of citizen participation, postings on social media is a positive thing. But on the other hands, sometimes information which circulates on social media is uncontrolled, accordingly confusing people, especially for those who do not have critical reasoning.

One effect of the existence of social media is the creation of an almost unlimited number of networks which may function within their own internal criteria of truth. At this point, we can see that this expansion reinforces the growing belief that there is no non-ideological stance in perceiving events, and accordingly there is also no truth which is ideology-neutral. This phenomenon can be understood as a movement towards post-truth. This is driven by another aspect of social media growth, that is, that social media had made new events possible, virtual events which may have little or nothing to do with actual experiences and events. From this angle, we can see that social media not only creates its own measures of truth but also its own cosmos of events, which has unembellished significances in encountering the others (Sawyer 2018).

On social media, people often choose news and information which are in line with their inclination and beliefs. They further defend their viewpoints which are based on their respective choice of information. They are convinced that this viewpoint is right, and the rest it is wrong. Some of them strongly believe in conspiracy theories, for example, that covid-19 is a form of Chinese, Zionist or Communist conspiracies. In Indonesia, the government often becomes the target of condemnation, not with critical and grounded arguments but based on conspiracy theories. Some people consider that this regime is anti-Islamic since it supports the closing of the mosque during the covid-19 pandemic.

Some people do not realise that consuming too much information can be 'intoxicating'. The swift flow of information, and from various directions, sometimes makes people confused and disoriented, if the people do not balance it with critical reasoning. One impact of the development of social media is the emergence of post-truth. Post-truth refers to a phenomenon in which some people consider an information to be true if it is in line with their beliefs or personal tendencies, not because the information is in accordance with facts (Widiyanto 2019). 
Post-truth accordingly underlines a confirmation bias within the society (Gilchrist 2018), and it may infect anyone from the clergy, the educated or the politicians.

One consequence of the post-truth era is the death of expertise (Nichols 2017). Due to the flow of information that penetrates all aspects of life, people become at ease to access the information they need. Armed with the existing knowledge on the internet, some people claim to be experts. They do not realise that not all information on the internet is true, since internet is an almost unfiltered world of information. They are also not aware that not all information can lead to knowledge.

The problem will become more complicated if policy makers do not adhere to critical thinking in responding to the flow of information which spread across various media. These policy makers ideally ground their policies on expert considerations, especially in this case, health experts. Policies on Covid-19 will be more effective and beneficial if the health experts are listened and taken into consideration. This is due to consideration that the experts uphold scientific ethics, most specifically honesty, impartiality, organised scepticism, and critical argumentation. These experts ground their opinions on reliable sources, such as books, journal articles and peer expert opinions. On that basis, experts will not simply justify beliefs or myths that develop in society without trying to verify them. One myth that develops in society (and unfortunately is also believed by some politicians) is that the Covid-19 cannot survive in tropical climates.

Policies based on expert judgment, especially health experts, will be more sustainable and have a positive impact on public interests. The covid-19 outbreak teaches some countries to be more autonomous. Lockdown is not only understood literally as social restrictions and physical distancing, but the momentum to reflect on and develop the potential that exists in the country. It is time for the country to appreciate and empower all the existing potential, including the expertise which is at hand in the country. The experts have obtained their best education. They will certainly be happy to help solve the nation's problems, if needed. The commitment of experts is for common good. It would be better if the researchers were given the flexibility and facilities to develop the covid-19 vaccine, so that they would not only become spectators and consumers of products developed in other countries. Indonesia has to see the bright side of the crisis, by empowering all of their existing potentials. As a nation, Indonesia is often appreciated by outside observers for their resilience. If the resilience is supported by political will of policy makers and the concern of all elements of society, Indonesia is very likely to win against covid-19 and become a self-reliant nation.

\section{Conservativism and the Sustainability of Nation-State}

One of the challenges in Indonesia is the reluctance of some people to maintain health protocols in order to break the spread of covid-19. This reluctance is to some extent grounded on conservatism in the society. Conservativism may infect religious people, educated people and politicians.

Conservativism spread to some educated people. They firmly believe that there is a big conspiracy behind the covid-19 outbreak, one of its targets is to foster fear among the people. In this juncture, we may reflect that education ideally lead people to think more broadly and open minded. The higher level of education ideally transforms people to be more open-minded. Unfortunately, there are some people who enjoyed a high level of education but on the contrary demonstrated the signs of close mind.

Some educated people also prefer to think within the context of their respective religious groups, rather than to think broadly in the framework of nationhood and humanity. Some of them prefer to be trapped in the 'cubicles' of their respective religious groups. In consuming the mainstream and social media, they only acknowledge information which is in line with their beliefs and personal tendencies, not because the information is in accordance with facts. In this 
vein, we have to consider, if educated people are not critical in consuming media, what about the ordinary people.

The tendency of conservativism among politicians is manifested in political attitudes which prioritise economic development over the safety and health of the nation. It can also be seen from political manoeuvres that emphasise gaining popularity, rather than providing more useful solutions for common good.

The future of Indonesia depends in some ways on their ability to overcome the problem of conservativism which taint some elements of the society. Progressive and broad-minded religious leaders have to do their best to enlighten the community, especially their respective religious communities. Progressive Muslim personages, for instance, have to play a role in explaining that religion is in harmony with common good. In the context of Covid-19, maintaining the continuity of human life (hifz al-nafs) is prioritised more than the implementation of congregational prayers even though they are obligatory congregational prayers such as Friday prayers, let alone supererogatory congregational prayers such as tarawih (non-obligatory night prayer during the Ramadan) and 'id al-fitr prayer (special prayer which commemorate the end of Ramadan). The broad-minded religious figures have to advise some Muslims who are ignorant of health protocols.

Progressive educated people have to enlighten the community, not only immerse themselves with academic matters alone. They are expected to be able to solve the problem of 'split personality' that infects some educated people. Split personality in this sense can be observed from the case in which some people are critical in carrying out scientific research, but not critical (not to say careless) in consuming news in the mainstream and social media. Progressive educated people should become role models by becoming educated people who have integrity, namely critical and careful in both carrying out scientific research and consuming media. These progressive educated people should enlighten their fellows who believe in conspiracy theories, that these theories are often baseless and do not provide any solutions to world problems, including covid-19 problems. We should not fill our brains with things that are not useful.

Enlightened politicians also have a responsibility to educate their fellow politicians, that the purpose of politics is ideally public benefit, not merely power and group interests. In this vein, protecting the community from covid-19 takes precedence over other the need for popularity.

Indonesia's struggle against covid-19 requires the support of all elements of the nations, including religious people, politicians, and educated people, not only relying on the hard work of health workers and the government. The people have to realise that the country belongs to all the people, and it should be protected from acts which threaten their common safety.

\section{Religious Conservativism and Its Challenges to Covid-19 Mitigation}

Conservativism among religious people can be seen from their rejection of the government's suggestion to comply with health protocols in organising religious worships. They argue that religious people should fear God more than fear covid-19. God's commands related to worship, especially compulsory worship, must be carried out in any condition, including during the covid19 outbreak.

Interestingly, this standpoint not only popular among conservative Islamic organisations, but also embraced by some members of moderate Islamic organisations like the Muhammadiyah and the Nahdatul Ulama. For example, one local figure from a moderate Islamic organisation maintained to held Friday prayers and tarawih prayers even though there has already been a fatwa (legal opinion) from the board of this organisation that congregational prayers at the mosque can be temporarily postponed for the sake of mutual safety (Interview with R). This figure referred to the opinions of another figure outside his Islamic organisations, who emphasised the obligation to carry out Friday prayers under any circumstances. One of its 
arguments is patience in observing religious duty (al-sabr ala al-ta'a). In this vein, we can see that some religious figures tend to take an opinion that is in accordance with his beliefs, even though the opinion is outside his organisation. This is one of the tendencies that we can observe especially in the post-truth era.

A small number of Muslims maintain to perform congregational prayers although they know that they have been tested positive for covid-19. They do not realise that covid-19 is a contagious disease. Performing congregational prayers in conditions infected by covid-19 is very risky for other worshipers. This is shown, among others, in the case in which someone who was tested positive for covid-19 but maintained to attend congregational prayer at the mosque (Anugrahadi 2020: Rachmawati 2020).

Another argument which is brought forward by conservative Muslims is that the place of worship is protected by God, so gathering in a place of worship is different from gathering in other places, let alone places such as discotheques and pubs. This is the basis for the consideration of some Muslims, so for example, they remain determined to hold a large meeting of the Tablighi Jamaat in Gowa, South Sulawesi from 19 to 22 March 2020. Even though the meeting was finally dissolved by the government, but most of the participants had been present at the venue a few days before the event (Apriyono 2020). This triggered the outbreak of the Covid-19 throughout the country.

They also argue that destiny is in the hands of God. God has laid down when we will die and for what reasons. If we have tried to avoid Covid-19 but God has determined that we will be infected by Covid-19, we will definitely be infected by this disease. But if God determines the opposite, we will not be infected by covid-19 even if we do not stick to health protocols, such as physical distancing and wearing masks in public places. This viewpoint is in some ways rooted in fatalistic theology (jabbariyya). This fatalistic theology is not really a problem when it only becomes a personal belief. But this kind of theology may jeopardise public safety if it is embraced by a group of militant people. Moreover, if they hold that belief and make it as a basis to contend the state authorities. Government regulations regarding physical distancing will not have any impact on public safety, if the community is not obedient. The regulation requires mutual and positive response from the community. Negative responses especially civil disobedience certainly endangers state institutions and public safety.

Enforcement of health protocols to break the proliferation of covid-19 sometimes gets opposition from other authorities in the community such as traditional or religious authorities. One of the obstacles to the implementation of health protocols in East Java, for instance, is the existence of religious authorities which sometimes in contrast with government authorities.

This is can be seen, for example, from the case in which the MUI of East Java allowed the people to carry out the takbir keliling (walking around praising God to celebrate the festivity of 'id al-fitr) by sticking to health protocol of covid-19 (Faiq 2020; 22 May 2020). Whereas at the same time the Ministry of Religious Affairs, The Central Board of MUI, The Muhammadiyah and the Nahdlatul Ulama had recommended Muslims not to carry out the takbir keliling for the sake of public safety. From March to May 2020, most regions in Indonesia (especially the red zones) did not organise Friday prayers and substituted it with dhuhr (midday) prayers at home. But interestingly, in Surabaya, which at that time was included in the red zones, some mosques continued to hold Friday prayers.

The case of religious leader's resistance in one highway in East Java is also worth remarking. From one angle, it might be triggered by the lack of politeness of officers in enforcing the rules of social restrictions during the Covid-19 pandemic. The conflict was finally resolved peacefully by forgiving each other (Widiyana 2020). However, we can see this case from another perspective, namely religious authorities sometimes constitute obstacles in the application of health protocols, if they understand religion narrowly, so that it is separated from the realm of science, ethics and common good. At ideal level, there should be harmony between these four domains. A good religious person has to respect scientific values, ethics and common good. 
The argument which is frequently put forward by some Muslims pertaining to congregational prayers during the covid-19 pandemic is that the mosque is a clean place. Before entering the mosque, people had performed ablution and were wearing clean clothes. Furthermore, they argue that the mosque is clean, worthier of opening compared to a dirty market. Some Muslims do not realise that even though the mosque is physically clean there is no guarantee that the mosque is free from the covid-19, because the virus is invisible. If a person is affected by covid-19 then joins the congregational prayer at the mosque then it endangers the whole congregation, even though they have performed ablution and are wearing clean clothes.

There are some cases which show that place of worship could be a place of the spread of Covid-19. Sixteen mosques and four churches in Surabaya, for example, were advised by the Surabaya city government to be closed for an unspecified time limit because in these places of worship there were positive patients of Covid-19 (Baihaqi 2020). It is also interesting to note that one mosque continues to hold Friday prayers during the covid-19 pandemic, but the people scattered outside the mosque when there was one person who died while performing Friday prayers and allegedly died due to covid-19 (Ikrar 2020).

Some Muslims believe that the closing of the mosque during the covid-19 pandemic is a form of the false Messiah conspiracy (Dajjal). Someone wrote their opinion on social media:

Dajjal's cunning trick manages to keep Muslims away from Friday prayers and congregational prayers in the mosque. It did not stop there, he even succeeded in creating a new model of worship (bid'a), namely physical distancing during performing the congregational prayers. But of all the slanders of the Dajjal, what makes us even more concerned is the sabotage of the mosque. Try to check some of the closest mosques. Many mosques are closed, even barred at the entrance gate, especially for people from outside the neighbourhood. Closing the mosque means claiming the mosque as belonging to a certain group. It should be noted that the mosque is public property (milk al-'amma). Even the endower of mosque is not entitled to claim it. What is worse and not realised, limiting the congregation means preventing Muslims from worshiping God. Is not this the great programme of the Dajjal?

The post-truth era reinforces the emergence of unsubstantiated suppositions from some people, including the conviction that covid-19 as a form of conspiracy which targets to weaken Muslims. Sawyer (2018) points out that post-truth appears to be contingent on constructing archives (which can be accessed and understood by the community) of self-referential data points which cannot be tested through other means of founding objective facts. A statement is considered true because it is in line with 'agreement network'. Any effort to question the statement is regarded as an effort to deteriorate the entire knowledge system rather than challenging a distinct statement.

Some Muslims reject the closing of the mosques during the covid-19 pandemic. The reason given by them is that the number of covid-19 victims in Indonesia is small, not sufficient to be categorised as plague ( $t a^{\prime} u n$ ) as mentioned in the hadith of the Prophet. Muslims should still carry out congregational prayers in mosques, especially Friday prayers. They stated, "We are very suspicious, Covid-19 is not a natural disease, but a major fabrication of the enemies of Islam, especially the Zionists and Communists, to destroy the order of Islamic law" (Santri Safari 2020).

The following verse is often employed as the basis of the argument of a group of Muslims who oppose the closing of mosques:

And who is more unjust than those who forbid the mention of Allah's names that in any of His houses of worship and strive to ruin them? It was not fitting that such should themselves enter them except in fear. For them there is nothing but 
disgrace in this world, and in the world to come, an exceeding torment (alBaqarah: 114).

The subsequent hadith is often used as the basis of arguments of a group of Muslims: "Verily, if Allah sends disease from heaven to the inhabitants of the earth, Allah will keep the disease away from those who enliven the mosque" (hadith narrated by Ibn Asakir (vol 17, p. 11) and Ibn 'Adi (vol. 3, p. 232).

\section{The Need for 'New Spirituality'}

Covid-19 outbreaks affect all aspects of life, whether in the realm of education, religion, economics, or politics. To break the spread of covid-19, physical distancing is needed, nevertheless these four domains rely much on the involvement of many people. In religious countries, the position of religion becomes important, not only as a domain which has been affected by the covid-19, but as an institution which may play a positive role in combating the covid-19.

The covid-19 outbreak forced religious leaders to redesign the organisation of worship. Muslim scholars, most notably those who are members of the MUI, the Nahdlatul Ulama and the Muhammadiyah, provide a reference for the Muslim communities in organising worship. They underline that the congregational prayers at the mosque should be reduced in order to avoid the spread of the covid-19. Even Friday prayers which are mandatory and are usually held at the mosques are allowed to be replaced with dhuhur prayers at home.

During the covid-19 pandemic, Muslims were expected to show their maturity, for a while holding worship at home, even though their longing for the mosque was very high. In this vein, there is a positive aspect that can be developed by Muslim families, namely the emergence of families as a centre of Islamic civilisation and education.

Covid-19 outbreaks should make Muslims think and contemplate their performance of worship, in the sense that it should be in harmony with the principles of public safety and common good, because religion was revealed for the betterment of human beings. Worship is not to be carried out rigidly without looking at the context of safety and common good.

Covid-19 should make Muslims realise that there is something more important than 'longing for mosque', namely 'love of God'. Love of God constitutes the basis of all religious rituals and worship. Love comes from heart. True Muslims certainly will not feel that their faith decreases just because they are temporarily unable to carry out congregational prayers at the mosque. This is in line with a well-known saying among Sufis (Vaughan-Lee 2012; Nasr 1986: Gülen 2009) that qalb al-mu'min bayt al-Rabb (the heart of a believer is the house of God).

The discourse of 'new normal life' which has been brought forward by the Indonesian government since the end of May 2020 was mainly for economic recovery which was hit by covid19. The government itself underlined that the education and religion are areas that need to be further considered for the implementation of new normal, for the sake of the nation's safety.

The new normal era is a transitional or liminal phase, in which the spread of the covid-19 is relatively controlled. The participation of all elements of the country is needed to suppress the spread of the corona virus. It would be better if the new normal era does not make everyone careless, competing to use freedom to carry out their respective activities. How elegant it would be if Muslims set role models in fighting the spread of covid-19. Islamic teachings about purification (tahara) are very relevant for the combat against covid-19, and will be more beneficial for the nation if it is coupled with the commitment to comply with Covid-19 health protocols, most specifically physical distancing.

During the new normal era, which began in June in Indonesia, mosques are allowed to be reopened for congregational prayers, but with strict health protocols, such as physical distancing, washing hands and ablution with soap, and spraying disinfectants. The Ministry of Religious 
Affairs provides a reference on how to carry out congregational prayers in this new normal era. The Ministry of Religious Affairs is however aware that there are some mosques that do not stick to strict health protocols when holding congregational prayers.

During the covid-19 pandemic, it would be better if Muslims developed a more substantive pattern of religiosity, that is, religiosity which is based on the enrichment of inner experience and deep spirituality (esotericism). Such Muslims will not be tempted on irrelevant issues such as the closing of the mosque during the covid-19 pandemic is a form of sabotage by the anti-Islamic regime, but realise that it is for the sake of public safety.

Esotericism in Islamic tradition is particularly embodied in Sufism (Nasr 1987: Schuon 1994; Smith 1984). Sufism is a form of Islamic religiosity that emphasises the richness of inner experience (Knysh 2019; Karamustafa 2007). This kind of religiosity serves as antithesis to patterns of religiosity which rely on exoteric experiences, which often results in formalistic religiosity. For the supporters of formalistic religiosity, the implementation of religious symbols is much more important than others.

In contrast to that, esoteric religiosity turns its attention to things which are substantial. The closing of the mosque from congregational prayers during the covid-19 pandemic did not discourage them. But, on the contrary, it constitutes Muslims' contribution to break the spread of covid-19. Muslims with esoteric religiosity are able to see this from a positive angle. During the closing of mosques from congregational prayers, Muslims have to reflect on the purpose and impact of their worship, whether it has an impact on spiritual maturity and common good.

Furthermore, it would be better if Muslims could develop a 'new spirituality'. This 'new spirituality' may serve as an alternative to exclusive spirituality (not to say 'egoistic spirituality'), for example, worshiping God only for inner satisfaction, and communicating with God only for fulfilling spiritual thirst.

The 'new spirituality' ideally gives room for the development of inner experiences and experiences which are in harmony with common good. Spirituality is not only enjoyed by its performers alone but should have an impact on the betterment of human being. New spirituality thus rests on the concept of public interest (maslaha).

In the level of practice, this spirituality emphasises the principles of maqasid al-shari'a (objectives of Islamic law) (Moosa 2014; Auda 2008; al-Jasani 1995), most specifically related to al-daruriyyat al-khams (five essentials of human well-being), namely hifz al-nafs (safeguarding life), hifz al-'aql (safeguarding intellect), hifz al-mal (protecting property), hifz al-nasl (protecting lineage) and hifz al-din (preserving religion). This new spirituality does not blindly apply the principle of 'safeguarding religion' without looking at other contexts and other aspects. This is due to the consideration that religion was revealed for the betterment of human beings. Performing religious teachings thus ideally has a positive impact on common good.

Furthermore, new spirituality is a form of religiosity which is conscious and responsive to the issues of health, environment and the future of humanity in general. This kind of spirituality will not negate, let alone oppose the development of science. This is due to the consideration that science is part of efforts to understand the 'signs of God in the universe' (ayat kawniyya). The followers of this new spirituality are aware that the verses of the Quran (ayat qawliyya) constitute guidance from God which has many meanings (polyvalent) and often have to be confirmed with 'signs of God in the universe'. The Quranic verses which are comprehended literally and without being situated in the context of the development of science will lead to the emergence of an oldfashioned and non-dynamic spirituality, which of course endangers public interest. In this vein, Muhammad Abduh's statement (see: Yusuf 2012) is worth underlining, that is, "al-Islam mahjub bi al-Muslimin" (the teachings of Islam (which are ideal) are often constrained by (the narrow understanding of) Muslims).

Spirituality is believed by many religious psychologists to have a positive impact on its performers. Patience (sabr) and trust in God (tawakkul) are believed to be able to increase positive thinking and behaviour which in turn may increase immunity and adversity. The new 
spirituality not only enhances the immunity of its performers, but also provides positive energy (most specifically empathy, altruism and compassion) which may contribute to solve the nation's problems, especially in breaking the spread of the covid- 19 .

\section{Building Indonesian Muslim Knowledge Culture}

Fighting Covid-19 is a joint task of the community and government. Muslims which constitute the majority in Indonesia should act as role models by developing religious and knowledge culture which have the potential in fighting the spread of the covid-19. The notion of 'Indonesian Islam', which is brought forward by some specialists, is grounded on living values among Indonesian Muslims. The Muhammadiyah and the Nahdlatul Ulama are considered by many specialists as guardians of Indonesian Islam. Azra (2006), for instance, stated that Indonesian Islam will sustain as long as the Muhammadiyah and the Nahdlatul Ulama remain in order. One of the most important contributions of the Muhammadiyah and the Nahdlatul Ulama is the alignment between Islamic and Indonesian values. Islam and Indonesian-ness are not two conflicting entities, but can go hand in hand. To be a good Muslim, one does not have to abandon Indonesian values.

Moderatism and cosmopolitanism constitute two main features of Indonesian Islam. In the realm of religious culture, these two virtues lead into tolerance and being not excessive in carrying out religious teachings. What is developed by the proponents of 'Indonesian Islam' is a mentality to acknowledge differences. This mentality needs to be introduced so that people are ready to live side by side. Insights into different cultures and religions also need to be introduced to strengthen this mentality. One does not have to wait to transform from 'knowledge' to 'wisdom' in order to acknowledge differences. What one needs to develop is the mentality of embracing differences.

Cosmopolitanism refers to a way of life which is engrained in the fundamental tenets of Islam, rooted in the belief that everyone is a part of common humanity and accordingly responsible towards one another (Aljuneid 2017). Cosmopolitanism allows Islamic teachings to come to terms with local cultures which in the ends leads to the emergence of new Islamic cultures which are rooted in society. Islam is understood more as spirit, rather than a formality of teachings which should be practiced without considering the specific contexts of the Muslim society. Javanese culture, for example, upholds the virtues of tolerance and harmony. This implies that Javanese society may make a significant contribution to the development of a multicultural society. In Javanese society, conservative people who tend to reject tolerance and harmony are labelled as 'not a genuine Javanese'.

The noble virtues in Javanese culture thus should not be contrasted with Islam, but on the contrary, should be married with Islamic values so that it becomes a practice of religious experience that is grounded in local culture, as exemplified by nine saints of Java (Walisongo) (Lukens-Bull 2008; Johns 1975). The 'deculturisation' movement echoed by some transnationalist Muslims is accordingly not relevant it the Indonesian context, because it deprives Indonesian Muslims from their local cultural contexts, which lead some Muslim to depreciate their respective cultures and to disrespect the plurality within the society.

The overflow of Covid-19 information in the internet demands Muslims to develop an attitude of moderatism. In this vein, moderatism is transformed as 'knowledge culture'. Knowledge culture mainly deals with epistemology constitutes the foundation of knowledge production in any given society (Bakar 2013). It is also concerned with knowledge ethos in a given culture.

Moderatism is of significance in building a balanced frame of mind, so that it can respond to information which covers both sides, not only confirm information which is in harmony with personal beliefs and tendencies. Moderatism in turn leads to the emergence of integrated 
personality, not split personality. Integrated personality in this sense refers to a condition where someone is critical both in carrying out scientific research procedures and in consuming media.

Moderate Muslims will not be tempted to believe in conspiracy theories, because these theories are difficult to find the basis of verification, and do not offer any solution to the actual. Moderate Muslims prefer to weigh information in terms of its balance and the value of its arguments. They will not accept any information or theory merely that it is in conformity with their beliefs.

Cosmopolitanism will lead to accommodative attitude towards the development of science, including, in this context, the latest scientific findings on covid-19. Cosmopolitan Muslims will realise that science is a universal treasure developed by many civilizations and religious traditions. Cosmopolitanism makes them aware of the importance of science which has been developed by human beings. Cosmopolitan Muslims will not be hostile to a branch of science merely because this particular branch of science happened to be developed outside Islamic tradition. They appreciate all branches of science, especially which may shed some light on the fight against covid-19.

Cosmopolitanism also lead to the emergence of open personalities, which in turn contribute to the establishment of 'open society' and knowledge society. The history shows that Muslim communities in the Malay-Indonesian archipelago were open to foreign cultures. According to some specialists (Shihab 1991; Stange 1986; Azra 1999), Islam was brought to Malay-Indonesian archipelago through trade and Sufism and accordingly determined the type of Islam which was open and tolerant.

This openness in terms of 'religious culture' should be elaborated further as 'knowledge culture', especially in responding to the development of Covid-19. Indonesian Muslims should develop themselves to be 'open society' and 'learning society', continue to learn and comprehend the latest development of science, most specifically concerning covid-19. Indonesian Muslims should not develop anti-science attitudes, because that would mean a setback for Muslim civilisation in Indonesia, and run in contrast to the spirit of cosmopolitanism that develops in the Indonesia Muslim tradition. Indonesian Muslims have to become role models in developing openness, especially openness to knowledge, so that they may contribute to the betterment of nation and humanity.

Covid-19 is a test for nation's security whether in terms of food, health, political, and economic security. Positive response and participation from all elements of society are vital in this venture. Indonesian Muslims as the majority in this country certainly have great opportunities in strengthening the social capital of the country. If Indonesian Muslims are able to develop moderatism and cosmopolitanism not only in the realm of 'religious culture' but also in the domain of 'knowledge culture', they will become role models for 'knowledge society', on the one hand, and they will become social capital for Indonesia to fight covid-19, on the other hand. Knowledge culture is one of the main social capital of the nation in dealing with covid-19. Without this knowledge culture, the community will fight science and health protocols, which of course jeopardises the safety of the nation in general. A nation is like a ship, in which if one makes a hole in the ship, it will certainly endanger mutual safety.

To conclude, the fight against covid-19 in Indonesia requires cooperation from all elements of society, most notably Muslims which constitute the majority in the country. The success of handling covid-19 in Indonesia thus depends partly on the participation of Muslims. One of the biggest challenges in handling covid-19 is that some Muslims are trapped in conservativism in understanding the relationship between Islamic teachings and covid-19 health protocol. Literal understanding of Islam, which is based on fatalistic theology, leads some Muslims to ignore and reject the health protocols which have been laid down by the government. In some respects, this negligence is further strengthened by existence of conspiracy theories which allude that covid-19 is a form of conspiracy that weakens Muslims and that the closing of mosques is the 
conspiracy of enemies of Islam. The post-truth era reinforces the tendency of this ungrounded thinking. Hence, the defence of the statement constitutes defence of the system of knowing.

To solve the problems of conservativism, there are at least two ventures which could be undertaken, namely developing 'new spirituality' and Indonesian Muslim 'knowledge culture'. The development of new spirituality is a necessity for Indonesian Muslims, especially in the context of the covid-19 pandemic. This spirituality not only enhances immunity of its performers but may have a positive impact on the development of empathy, altruism and compassion, which in turn could contribute to the public interest, most specifically in dealing with covid-19.

The elaboration of Indonesian Muslim knowledge culture is also vital in overcoming covid-19 pandemic. Conservativism, which especially strengthens in the era of post-truth, represents a system of knowing, which originates from a narrow understanding of the teachings of religion and social realities. Moderatism and cosmopolitanism which have been developed as 'religious culture' need to be transformed into 'knowledge culture', which will become an important social capital in tackling covid-19 pandemic, most specifically in responding to the health protocols and the latest development of science.

\section{References}

Aljuneid, Khairudin. 2017. Muslim Cosmopolitanism: Southeast Asian Islam in Comparative Perspective. Edinburgh: Edinburgh University Press.

Anugrahadi, Adi. 2020. Nekat Tarawih Puluhan Jemaah Musala di Tambora diduga Terinfeksicovid-19. https://www.liputan6.com/news/read/4250588/nekat-tarawih-puluhanjemaah-musala-di-tambora-diduga-terinfeksi-covid-19. Retrieved: 11 May 2020.

Apriyono, Ahmad. 2020. Klaster Baru yang Mengerikan itu Bernama Ijtima Tablig Gowa. https://www.liputan6.com/regional/read/4226063/klaster-baru-yang-mengerikanitu-bernama-ijtima-tablig-gowa. Retrieved: 3 April 2020.

Auda, Jasser. 2008. Maqasid al-Shari'a: A Beginner's Guide. London: International Institute for Islamic Thought.

Azra, Azyumardi. 1999. Opposition to Sufism in the East Indies in the seventeenth and eighteenth century. In, Friedrich de Jong and Bernd Radtke, Islamic Mysticism Contested: Thirteen Centuries of Controversies and Polemics, pp. 53-58. Leiden: Brill.

Azra, Azyumardi. 2006. Indonesia, Islam and Democracy: Dynamics in a Global Context. Jakarta: Solstice Publishing.

Baihaqi, Amir. 2020. Jemaah Terpapar Corona 20 Tempat Ibadah di Surabaya ini Ditutup Sementara. https://news.detik.com/berita-jawa-timur/d-5052342/jemaah-terpaparcorona-20-tempat-ibadah-di-surabaya-ini-ditutup-sementara. Retrieved:13 June 2020.

Bakar, Osman. 2103. Islamic civilization as a global presence with special reference to its knowledge culture. Islam and Civilisational Renewal 4(4): 512-528.

Faiq, Azmi. 2020. MUI Jatim Tidak Larang takbir Keliling Ini Syaratnya. https://news.detik.com/berita-jawa-timur/d-5019655/mui-jatim-tidak-larang-takbirkeliling-ini-syaratnya. Retrieved:18 May 2020.

Gilchrist, Alan. 2018. Post-truth: an outline review of the issues and what is being done to combat it. Ibersid 12 (2): 13-24.

Gülen, Fethullah. 2009. Emerald Hills of the Hearth: Key Concepts in the Practice of Sufism. New Jersey: Tughra Books.

Ikrar, Amin. 2020. Pria ini Tiba-tiba Meninggal saat ShalatJumat Jemaah Masjid PanikBerhamburan. https://bogor.pojoksatu.id/baca/pria-ini-tiba-tiba-meninggal-saatshalat-jumat-jemaah-masjid-panik-berhamburan. Retrieved: 19 April 2020.

al-Jasani, Ismail. 1995. Nadariyyatal-Maqasid 'inda al-Imam Muhammad al-Tahir ibn 'Ashur. Cairo: al-Ma'had al-'Alami li al-Fikr al-Islami.

Johns, A.H. 1975. Islam in Southeast Asia: reflections and new directions. Indonesia 19(1): 33-55. 
Karamustafa, Ahmet T. 2007. Sufism: The Formative Period. Berkeley: University of California Press.

Knysh, Alexander. 2019. Sufism: A New History of Islamic Mysticism. Princeton: Princeton University Press.

Lukens-Bull, Ronald. 2008. The traditions of pluralism, accommodation, and anti-radicalism in the pesantren community. Journal of Indonesian Islam 2(1): 1-15.

Moosa, Ibrahim. 2014. On reading Shatibi in Rabat and Tunis. In, Adis Duderija (ed.). Maqasid alShari'a and Contemporary Reformist Muslim Thought: An Examination, pp. 177-192. New York: Palgrave Macmillan.

Nasr, Seyyed Hossein. 1987. Traditional Islam in the Modern World. London and New York: KPI

Nasr, Seyyed Hossein. 1986. The prayer of the heart in Hesychasm and Sufism.Greek Orthodox Theological Review. 31(1): 195-203.

Nichols, Tom. 2017. The Death of Expertise. Oxford: Oxford University Press.

Rachmawati, Fitri. 2020. Pasien Positif Covid-19 yang Videonya Viral Tolak Diisolasi NekatShalat. https://regional.kompas.com/read/2020/04/30/08003661/pasien-positifcovid-19-yang-videonya-viral-tolak-diisolasi-nekat-shalat?page=all. Retrieved: 30 April 2020.

Santri Safari. 2020. Jum'atan Dilarang, Gus Najih Marah. https://www.youtube.com/watch?v=w6rrv2oK9ms. 2 Retrieved: April 2020.

Sawyer, M.E. 2018. Post-truth, social media and the real as phantasm. In. Stenmarket al. (eds), Relativism \& Post-truth in Contemporary Society, pp. 55-70. Macmillan: Palgrave.

Schuon, Frithjof. 1994. Memahami Islam. Translated by Anas Mahyudin. Bandung: Pustaka.

Shihab. Alwi. 1991. Islam Sufistik: "Islam Pertama" dan Pengaruhnya hingga Kini di Indonesia. Bandung: Mizan.

Smith, Huston. 1984. Review of Knowledge and the Sacred, by Seyyed Hossein Nasr. Philosophy, East and West 34(1): 111-113.

Stange, Paul. 1986. Legitimate mysticism in Indonesia. Review of Indonesian and Malaysian Affairs 20(2): 76-117.

Vaughan-Lee, Llewellyn. 2012. Sufism: The Transformation of the Heart. California: The Golden Sufi Center.

Widiyana, Esti. 2020. Perseteruan Habib Umar Assegaf vs Petugas PSBB di Surabaya Berujung Damai. https://news.detik.com/berita-jawa-timur/d-5026112/perseteruan-habibumar-assegaf-vs-petugas-psbb-di-surabaya-berujung-damai. Retrieved: 23 May 2020.

Widiyanto, Asfa. 2019. Islam, multiculturalism and nation-building in the post-truth age.AtTamaddun 14(1): 1-12.

Yusuf, Aasia. 2012. Islam and modernity: remembering the contributions of Muhammad 'Abduh (1849-1905). Islam and Civilisational Renewal 3(2): 355-369. 